\title{
Knotted Histories
}

\section{MIRANDA JOHNSON}

There are lieux de mémoire, sites of memory, because there are no longer milieux de mémoire, real environments of memory.

Pierre Nora, "Between Memory and History: Les Lieux de Mémoire"

It is time ... to openly and honestly confront and take ownership of our past. . . Let's remember, understand, embrace and own our history, because it is a big part of who we are as a nation.

Vincent O'Malley, The New Zealand Wars Ngā Pakanga o Aotearoa

\begin{abstract}
In the 1960s, my grandfather Ormond Wilson devoted himself to restoring the site of the last fixed battle of the New Zealand wars, Te Pōrere, in the central North Island. As chair of the recently formed Historic Places Trust, Ormond was involved in the creation of what the French historian Pierre Nora has called "lieux de mémoire" or sites of memory. Nora argues that such sites are a modern phenomenon that demonstrate the rupture between traditional environments of memory (or "milieux de mémoire") and historical research and consciousness in a modern sense. In this essay, I reflect on how Ormond's work can be read differently, as revealing an entanglement or "knotted" historical practice as he worked at Te Pōrere, a place with which his family had a longer connection.
\end{abstract}

Ours is the only car when we pull up and park in front of the signs introducing visitors to Te Pōrere pā, the site of the last fixed battle of the New Zealand wars. It's mid-winter and we have driven slowly and determinedly along state highway 47 , the road that crosses the vast eerie landscape of the Tongariro Volcanic plateau and connects National Park to Tokaanu, resisting the feeling of being pressed into the earth by the lowering sky. The mountains Ruapehu and Tongariro are hidden behind wreaths of clouds and we nearly miss the sign to the pā, up a gravel road. It is a short, bumpy, journey to the site that makes literal the metaphor that roads divide as well as connect. From the left-hand passenger window is a view of undulating native bush nourished by the upper reaches of the Whanganui river; from the right, we are confronted with the waste of recently cut plantation forestry. Silvered trunks and broken branches litter the muddy ground.

For many New Zealanders, the central North Island is a tourist destination. We could have turned off the state highway to drive up to the Whakapapa ski field or find the carpark at the entry to the Tongariro Alpine crossing. Yet this is also a deeply storied place, of ancestral beginnings, of conflict and flight, of homemaking and refuge, as well as of resource gathering and spiritual sustenance. The area of Te Pōrere features in many Ngāti Tūwharetoa histories, known as Te Pōrere-o-Ngatoroirangi, the place where the tōhunga of the Arawa waka came to commune with his brother Hoturoa; and as Te Pōrere-o-Rereao, referring to the grandson of Tūwharetoa, Rereao, who rested here before swiftly attacking Ngāti Hotu on a ridge west of Ngāuruhoe (hence "pō" referring to night and "rere" referring to flight). ${ }^{1}$

Journal of New Zealand Studies NS29 (2019), 89-96 https://doi.org/10.26686/jnzs.v0iNS29.6264 
In September 1869, Tūwharetoa kin brought Te Kooti Arikirangi Te Turuki here with the whakarau (the captives who had been taken to the Chatham Islands with Te Kooti when he was imprisoned there). They built two redoubts, a lower and an upper one on an ancient pā known as Mahaukura from which they engaged the Māori and colonial forces that had been pursuing them around the central North Island. This was only the second prepared position Te Kooti and his followers had constructed; the first at Ngatapa in January 1869 had led to his swift defeat and flight. Between this battle and the engagement on October 4 at Te Pōrere, Te Kooti had travelled in the Urewera district and briefly formed an alliance with Rewi Maniapoto; by the beginning of September he was in control of the strategically important Tokaanu area, the juncture of several crossroads. On 25 September, Te Kooti's and Rewi's forces were attacked at Te Pononga, after which Rewi returned to the Waikato.

It is unclear when the redoubts at Te Pōrere were constructed, and by whom, but they were poorly done. The forces who attacked Te Kooti's supporters at the pā-the majority (about 400) of whom were Māori, from Te Arawa, Ngāti Kahungunu, and Ngāti Upokoiri, and under the command of Te Keepa Rangihiwinui, Henare Tomoana, Renata Kawepo, and Thomas McDonnell among others - quickly routed those defending the redoubts, killing at least 37 and taking more than 30 prisoners, mostly women and children. Te Kooti escaped with the whakarau into the bush. ${ }^{2}$

Of the many consequences for Tūwharetoa in supporting Te Kooti, one was the opening up of the district to road building. ${ }^{3}$ Hence a common historical irony: the infrastructure that delivers visitors to this lieu de mémoire (site of memory) today is itself the product of the conflict that later becomes the subject of restoring, learning, remembering, mourning, contesting, and understanding.

Pierre Nora, the French historian who coined the term lieux de mémoire over thirty years ago, drew a sharp distinction between sites of memory - the places where history crystallizes and in which we late moderns, ourselves "hopelessly forgetful," are now interested — and milieux de mémoirethe traditional environments that hosted a collective and "integrated" memory. The latter, according to Nora, "ceaselessly reinvents tradition, linking the history of its ancestors to the undifferentiated time of heroes, origins, myths." 4 The former is a practice of cool detachment, more concerned with facts and evidence rather than ancestor worship. He drew a distinction, in other words, between memory as a practice that bonded humans together through the past-in-thepresent; and that of history as a representation of the past, performed in the knowledge that the past is ruptured from our present and is only partially recoverable.

I've brought my family to Te Pōrere not only to learn about the battle that took place here in 1869 but also because my grandfather, Ormond Wilson, played an instrumental role in restoring the site in the 1960s, once he was appointed as chair of the Historic Places Trust in 1958. I'm carrying with me a copy of the booklet he wrote about the site and the events of 1869, War in the Tussock (1961). It's a work that, according to historian James Belich, makes the site "historiographically exceptional, in that a good modern account exists," although the events themselves were less historically significant than previous battles, revealing Te Kooti's "imperfect tactical understanding of the modern $p a$, and his reluctance to accept the strategic limitations this imposed on his operations." 
The restoration of the site was one of the first places that Ormond worked on as chair, following the agreement of the Ngāti Tūwharetoa Trust Board in 1958 that the Historic Places Trust would care for the site which remained Māori reserve land. No doubt the Trust Board was influenced by John Te Herekiekie Grace, whose history of the iwi would come out in 1959 and who was a fellow board member of the Historic Places Trust. Grace's knowledge of the history of his iwi and the region also influenced Ormond, and his history Tuwharetoa: A History of the Maori People of the Taupo District was an important source for Ormond's account of the battle at Te Pōrere.

From 1959 through to the mid-1970s (beyond his formal tenure as chair which ended in 1972), Ormond visited Te Pōrere weekend after weekend, cutting back the gorse, removing flax that had grown over the ramparts, cutting a track from what is now the carpark up to the redoubts, and overseeing the building of a bridge. A decade after he began his work at the site, he was still deeply involved in its maintenance. As he wrote to fellow trust board member Bob Burnett in 1969, when he was 62: "I was going up to Te Porere early, to encourage Dimitrios, mow the grass again, and paint the notice boards, and then see the builders start work on Saturday morning. No use going early now [because of the rain]. I'll go later in the day and hope for a clearance of the weather on Friday ... One advantage of the delay however is that I'll be able to supervise some repairs to a deep-well pump which has broken down. Would have gone off a bit anxiously if I hadn't seen it start before I left." 6

As well as the relentless physical labour at the site, Ormond doggedly hunted down historical sources in preparing the booklet. His personal correspondence files, held at the Alexander Turnbull Library, as well as the institutional files of the Trust (now Heritage New Zealand Pouhere Taonga) are replete with clippings from newspapers at the time of the conflict, official dispatches, as well as later accounts by Gilbert Mair, James Cowan, and others who visited the site in the early twentieth century, often with veterans of the battle. Numerous letters that Ormond wrote to a wide range of scholars, intermediaries, and knowledge keepers about Te Pōrere, Te Kooti, and the Ringatū church, attest to his concern to get the facts right. Ōpōtiki-based Norman Perry, a Pākehā who had worked closely with Sir Āpirana Ngata on land development schemes, who fought with the Māori Battalion during World War II, and who was close with some Ringatū elders, helped Ormond decode Te Kooti's flag, held at the Dominion Museum and which was displayed at the opening of the site in 1961. Ormond exchanged ideas and sources with Leo Fowler who had recently helped establish the Gisborne museum and was a member of the Polynesian Society; and he consulted his friend Charles (Charlie) Moihi Te Arawaka Bennett, commander of the Māori Battalion, scholar, and high commissioner to the Federation of Malaya, about the redoubts and Te Kooti's military strategies.

Before joining the Trust, Ormond had not shown any particular interest in New Zealand history. Indeed, up until this point, he had lived a remarkably global life. Although he grew up in a reclusive farming family in the Rangitikei, in the 1920s he was sent, like other sons of the "middle-class gentry," to Oxford where he attended Lincoln College in the 1920s. ${ }^{7}$ He travelled extensively in Germany in the 1930s and visited the USSR in 1939, having returned to Europe after losing the seat he had unexpectedly won as the youngest member of the first Labour government in New Zealand in 1935. Based in London during the war, he began working for the Overseas Service of the $\mathrm{BBC}$ - thus avoiding enlistment — with his soon-to-be wife Margery Wace (my grandmother).

Journal of New Zealand Studies NS29 (2019), 89-96 https://doi.org/10.26686/jnzs.v0iNS29.6264 
It was a thrilling experience. In charge of arranging talks for the Pacific zone, he met luminaries, intellectuals, politicians and soldiers from all over the empire whose "readiness to respond to our appeals," he wrote in his memoirs, An Outsider Looks Back: Reflections on Experience (1982), "reflected our exalted sense that the defence of Britain was also the defence of western civilization." 8

Margery died unexpectedly following the birth of their second child (who also died) in 1944. Ormond returned to New Zealand in 1945 with his young daughter Cecilia (my mother) to pick up the pieces of his life. He remarried, to an old flame Rosamund Rolleston, and they established a composite family at his farm Mt Lees, near Bulls. He also reentered New Zealand politics, serving a second term for the Labour government in 1946-1949. Although now living on family land, and drawn back into New Zealand affairs, he continued his avid study of international politics, writing critical opinion pieces on the ANZUS alliance in Here and Now that questioned New Zealand's willingness to accept American hegemony. ${ }^{9}$ In 1956, an admirer of Mao's poetics as well as politics, he travelled to China with a group of academics, artists, and intellectuals including James Bertram, a visit that he had long anticipated. He believed that American global power would only last a few decades and "we would then turn for guidance and example to the oldest and most populous nation on earth." "If If his wartime experience had confirmed the importance of "Western civilization," the post-war decades of decolonization and the developing Cold War encouraged him to consider other civilizational possibilities.

His appointment to the Trust in 1958 awakened more local concerns, a "sense of history" and curiosity about the shaping of his own country. I'm interested in his shift in interests, away from international political affairs and towards the history of nation, of colonization, and racial conflict. What accounts for this change in focus? One answer is surely to be found in the specific context and the period in which he was working. As well as the influence of Grace that I have mentioned, Ormond was also inspired by New Zealand historians, notably his friend and co-member of the Trust, J. C. Beaglehole. He was particularly impressed by Keith Sinclair's 1957 account The Origins of the Maori Wars, a well-thumbed copy of which is in his library along with Grace's history of Tūwharetoa. Ormond's vigorous correspondence with Ruth Ross-including about her research for the article on the translation of the Treaty of Waitangi she eventually published in 1972 and that would go on to have a political life of its own-reveals that he was part of a generation of intellectuals committed to using the empirical methods of historical research for the moral purpose of restoring to the nation an accurate understanding of its past.

Ormond and his contemporaries were in many respects the late moderns of Nora's text - critical of earlier generations of historians, scientific in their approach to evidence, doubtful of memory and its slippages. Indeed, as Ormond wrote, somewhat paradoxically, in his memoirs: "My historical researches in recent years have left me skeptical of much claimed remembrance of events long past. Many such recollections seem to be derived from hearsay . . . and they contain palpable distortions of fact."11 In their obituary, R. I. M. Burnett (another fellow Trust member) and J. E. Traue proposed that he held a "native scepticism," describing his frequent visits to the Turnbull library during the 1960s through to the 1980s (he died in 1988) as he hunted facts. ${ }^{12}$ I suspect this attention to facticity was more than "native," borne as much from his own professional and 
personal experiences. His work at the BBC during the war had impressed on him a keen sense of why facts mattered in a context of war-time propaganda.

Yet can the practice of empirical, historical research be so cleanly distinguished from the work of memory? Nora's hugely influential formulation even implied the colonization of memory by history. But his claims have, in turn, been subject to extensive critique. His insistence on a binary distinction between memory and history was too neat. His description of memory's traditional life was too romantic. And he paid inadequate inattention to the legacies of French empire. ${ }^{13}$ While he usefully explained how "sites" of memory in the form of physical places are in fact abstractions, artificially constructed in order to enforce a particular version of "official" history, critics point to the ways in which such sites themselves become subject to political contestations by groups whose versions counter the official account. In these conflicts, "history" does not simply replace or repress "memory." Rather, there is ongoing tension and even antagonism between official historical accounts and counter-memories. Productively, these engagements can produce new histories. The work of institutions such as the Waitangi Tribunal, the Office of Treaty Settlements, and the Ministry of Culture and Heritage has over the past three decades been to try to reconcile or negotiate different historical accounts and understandings held by iwi, hapū, and other New Zealand constituencies.

In the wake of these critiques, the historian and literary scholar Michael Rothberg proposes the concept of "noeuds de mémoire" or knots of memory, rather than abstracted sites of memory which he argues imply a static rather than dynamic conception of the relationships between past and present. ${ }^{14}$ Conceptualizing collective memories as "knotted" invites different questions and demands critical attention to temporal and spatial processes that are more entangled than those allowed for by Nora. Rothberg suggests other questions concerning the production of collective memory and memorialization - the restoring of the redoubts at Te Pōrere for example, that itself is dependent on the possibilities of accessing such a site on state highways built in the wake of war. $^{15}$

Thinking with history's knots seems to me a useful way of exploring Ormond's motivations in his tireless efforts at Te Pōrere, some of which were less conscious than the clear intention to make of the "site" something of national interest. Restoring Te Pōrere and writing the booklet War in the Tussock entangled him in a knot of familial connections to places and events of the past. I cannot help but think that his deepening historical consciousness was deeply entwined with his latent knowledge of his family's involvement in colonization. Perhaps he was even troubled by this knowledge.

Lieutenant-Colonial Thomas McDonnell, one of the military leaders of the forces opposing Te Kooti, was appointed by J. D. Ormond, who was himself Ormond Wilson's grandfather, my greatgreat-grandfather. In September 1869, J. D. Ormond had succeeded Donald McLean as superintendent at Napier when McLean-his close colleague and confidante-was appointed Minister of Native Affairs. Ormond's jurisdiction included the Taupō district and as Te Kooti travelled through this country following his dramatic escape from the Chatham Islands, he became Ormond's problem, to be "got rid off" as quickly as possible, as the latter put it in one personal note to McDonnell, and that Ormond (Wilson) cites in the booklet. ${ }^{16}$ This had become all the more

Journal of New Zealand Studies NS29 (2019), 89-96 https://doi.org/10.26686/jnzs.v0iNS29.6264 
urgent because gold-bearing reefs had been found in the Kaimanawa ranges earlier that year and over which there was much rivalry. (McDonnell's own brother William had put in a claim.) During the battle at Te Pōrere, just a month or so after J. D. Ormond had taken up the role of superintendent, he had "general control of operations" although he was not directly involved in the fighting and he had no military experience. ${ }^{17}$

In War in the Tussock, Ormond (Wilson) does not acknowledge the fact that he is the grandson of the man who directed, albeit from afar, the forces against Te Kooti, although he quotes from his ancestor's dispatches and correspondence extensively. This is no doubt due to the fact that Ormond wrote the pamphlet according to the conventions of objective history that he had admired first as a student at Oxford. Personal attachments were irrelevant to writing in that historical genre. Nonetheless, at the opening ceremony of the restored pā on 18 February 1961, Ormond did sound a more partisan note, observing in his speech that Te Kooti was a "much misjudged man" and that the actions of "our forebears ... . was much to [their] discredit." 18 While he did not directly name his own grandfather, the connection was at least implicit and would likely have been known to some of those gathered at the ceremony.

It may well be that, as Vincent O'Malley argues, New Zealanders (particularly non-Māori) have largely forgotten the wars of the nineteenth century, and that we have not therefore fully embraced our past, the good and the bad. ${ }^{19}$ However, to do so in O'Malley's terms requires us to think of the past as a thing, an object to be grasped and understood. This way of thinking about history also informed Ormond's work, and his contemporaries at the Historic Places Trust, as they restored "sites" of the past for the purposes of understanding and thickening national identity in the present. But this conceptualization of history is not the only way of understanding relationships between past, present, and future. As many Māori historians have argued, the practice of whakapapa invites another sense of history in the layering of relationships - human and non-human - in and through time. Thinking about memory as "knotted"-or as plaited, the strands of which locate self and work in an endless and encompassing genealogy, as Alice Te Punga Somerville proposes_- ${ }^{20}$ might help us to reconsider the history of Te Pörere, and indeed other sites of the New Zealand wars. These places not only commemorate nineteenth-century events. They are also the grounds of ongoing cross-cultural and dynamic encounters, confrontations, disputes, and reconciliations.

As Judith Binney put it, "no one owns the past; no one owns that complexity of shared experiences and human and cultural exchange. The past is inhabited by all our ancestors." ${ }^{21}$ Thinking in terms of knots, plaits, and entanglements refigures the "site," not only as a place that preserves the memory of a battle long past but also as a demand on us in the present. This is one that entwines associations and actor-ancestors at different moments in time, and that might activate debates in which we reckon with how our own future descendants are implicated in, enabled or constrained by, how we have or have not accounted for the past. In such a debate, history is not just academic.

Perhaps it is not simply the case that we in the present have forgotten past events - as the injunction to "remember" insists upon — but rather that, for many of us, our entanglements through time, our relationships to historical events and their agents (some of whom are our ancestors), are not lived in ways they were by earlier generations. Our milieu in 2019, in a country of five million people whose multiple heritages extend to every continent and who are intricately connected through

Journal of New Zealand Studies NS29 (2019), 89-96 https://doi.org/10.26686/jnzs.v0iNS29.6264 
virtual webs, but perhaps not as consciously located in historical time, is very different from that of 1969 or 1869. Five generations on from J. D. Ormond's world, knowledge of familial connections - and consequent responsibilities - cannot be assumed even as they could in my grandfather's lifetime. We have to bring them out of latency, into acknowledgement.

In such a changed milieu, the work of history, including how "history" as a school subject should be taught will - and indeed must - change. What is required is more than the creation of sites of memory where we officially recount events of the past - as significant as these sites are and as critical as the work of restoring them is. We need to do more than "own" the past, as O'Malley charges, an argument that reifies history and turns it into a contestable moral object. What we must also attend to are the knots that entwine us, more or less loosely, in histories that make our choices in the present possible and that oblige us to each other in ongoing relationships of give and take.

In so doing, we will find ourselves faced with a further paradox: what the philosopher Wendy Brown refers to as an "oxymoronic edge" in liberal democracies. This is the point at which the liberal, sovereign, subject might, paradoxically, choose to escape from freedom, to submit to another kind of authority, and become subject to demands and responsibilities not only of their own making. ${ }^{22}$ In other words, understanding ourselves as living in knotted, or plaited, relationships constituted in the past and lived in the present will demand something other of us than what is modelled in the idea of the free, critical-rational actor in the public sphere. It is not only that we need to reckon with, embrace, or better understand our past. We also need to attend to how acknowledging our knotted-ness makes us different kinds of political and historical subjects and citizens.

During our mid-winter visit to Te Pōrere, my five-year-old runs around the lower redoubt, looking for the way out. "It's a maze!" he calls out. It was a metaphor my grandfather also used in his booklet, critiquing the design as "too complicated to be of real use." 23 And yet perhaps our visit on this cold mid-winter day serves another purpose, an acknowledgement of a bond, a tie with the past, and a responsibility of return.

I would like to thank Jonathan West and Sandy Callister for their comments on this essay, staff at Heritage New Zealand and at the Alexander Turnbull Library who provided access to files, and the Stout Research Centre for New Zealand Studies for providing an academic home as I worked on aspects of this story during 2019.

${ }^{1}$ On these histories, see Waitangi Tribunal, Te Kāhui Maunga: The National Park District Inquiry Report, vol. 1 (Wellington, 2013), chapter 2.

${ }^{2}$ See Ormond Wilson, War in the Tussock: Te Kooti and the Battle at Te Porere (Wellington: National Historic Places Trust, 1961).

${ }^{3}$ See Waitangi Tribunal, Te Kāhui Maunga, chapters 3 and 4. Ultimately, Tūwharetoa also made a tuku of the mountains and surrounding area, which formed New Zealand's first national park. On this, see also Paulette Wallace, "Approaching Cultural Landscapes in Post-Settler Societies: Ideas, Policies, Practices" (PhD thesis, Deakin University, 2013).

Journal of New Zealand Studies NS29 (2019), 89-96 https://doi.org/10.26686/jnzs.v0iNS29.6264 
${ }^{4}$ Pierre Nora, "Between Memory and History: Les Lieux de Mémoire," Representations 26 (Spring, 1989): 7-24.

${ }^{5}$ James Belich, The New Zealand Wars and the Victorian Interpretation of Racial Conflict (Auckland: Auckland University Press, 1986), 283. On Te Kooti more generally, see Judith Binney, Redemption Songs: A Life of Te Kooti Arikirangi Te Turuki (Auckland: Auckland University Press with Bridget Williams Books, 1995).

${ }^{6}$ Ormond Wilson to Bob Burnett, 31 January 1969, Robert Ian McKenzie Burnett papers, MS-Papers5317-1, Alexander Turnbull Library.

${ }^{7}$ Ormond Wilson, An Outsider Looks Back: Reflections on Experience (Wellington: Port Nicholson Press, 1982), 5.

${ }^{8}$ Wilson, An Outsider Looks Back, 120.

${ }^{9}$ See for example, Ormond Wilson, "ANZUS and Us," Here and Now (December, 1952), 15-16.

${ }^{10}$ Wilson, An Outsider Looks Back, 155.

${ }^{11}$ Wilson, An Outsider Looks Back, 2.

${ }^{12}$ R. I. M. Burnett and J. E. Traue, “George Hamish Ormond Wilson, 1907-1988” Turnbull Library Record 21, no. 2 (1988).

${ }^{13}$ See for example Tony Judt, "A la Recherche du Temps Perdu," New York Review of Books (December 3, 1998), 54; and Hue-Tam Ho Tai, "Remembered Realms: Pierre Nora and French National Memory," American Historical Review 106, no. 3 (2001): 906-22.

${ }^{14}$ Michael Rothberg, "Introduction: Between Memory and Memory: From Lieux de Mémoire to Noeuds de Mémoire," Yale French Studies 118/119 (2010), 8.

${ }^{15}$ Rothberg, "Introduction," 9-10.

${ }^{16} \mathrm{~J}$. D. Ormond, quoted in Wilson, War in the Tussock, 31.

${ }^{17}$ Ormond, quoted in Wilson, War in the Tussock, 30.

${ }^{18}$ Ormond Wilson, quoted in Dominion, 20 February 1961.

${ }^{19}$ Vincent O'Malley, The New Zealand Wars Ngā Pakanga o Aotearoa (Wellington: Bridget Williams Books, 2019), 35.

${ }^{20}$ Alice Te Punga Somerville, "Genealogies, Futures, Metaphors, and the Opposite of Zombies," in Pacific Futures: Past and Present, ed. Warwick Anderson, Miranda Johnson, Barbara Brookes (Honolulu: University of Hawai'i Press, 2018), 77.

${ }^{21}$ Binney, Redemption Songs, 5.

${ }^{22}$ Wendy Brown, "Religious Freedom's Oxymoronic Edge," in Politics of Religious Freedom, ed. Winnifred Fallers Sullivan, Elizabeth Shakman Hurd, Saba Mahmood, and Peter G. Danchin (Chicago: University of Chicago Press, 2015), 324-34.

${ }^{23}$ Wilson, War in the Tussock, 37. 